\title{
A Case of Acute Bilateral Ptosis: SURF-1 Mutation
}

$$
\text { Akut Bilateral Pitozisle Başvuran Olgu: SURF-1 Mutasyonu }
$$

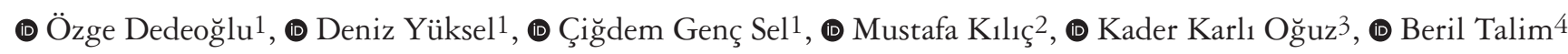

${ }^{1}$ Dr. Sami Ulus Children's Hospital, Clinic of Pediatric Neurology, Ankara, Turkey

2Dr. Sami Ulus Children's Hospital, Clinic of Metabolism, Ankara, Turkey

3Hacettepe University Faculty of Medicine, Department of Radiology, Ankara, Turkey

${ }^{4}$ Hacettepe University Faculty of Medicine, Department of Pediatrics, Pathology Unit, Ankara, Turkey

Keywords: Ptosis, SURF-1 mutation, mitochondrial disease

Anahtar Kelimeler: Pitozis, SURF-1 mutasyonu, mitokondriyal hastalık

\section{Dear Editor,}

A 14-month-old girl presented with a one-week history of bilateral ptosis without fluctuations in the intensity and distribution over time. Development stages were normal with no history of seizure, trauma or intoxication. On neurologic examination, bilateral ptosis was present, but eye movements, pupillary light reflexes, fundus and other cranial nerve functions were normal. Toxic, infectious, and metabolic causes that could affect the brainstem were considered in the differential diagnosis. Laboratory investigations revealed elevated serum lactate $(31 \mathrm{mg} /$ $\mathrm{dL}$; reference values: $8-22 \mathrm{mg} / \mathrm{dL}$ ) with normal pyruvate levels (0.37 mg/dL; reference values: $0.3-0.9 \mathrm{mg} / \mathrm{dL})$. Cerebrospinal fluid (CSF) analysis demonstrated elevated lactate level $(32 \mathrm{mg} /$ $\mathrm{dL}$; reference values: $5-19 \mathrm{mg} / \mathrm{dL}$ ) with normal protein and glucose levels. Brain magnetic resonance imaging (MRI) showed bilateral and symmetrical non-enhancing lesions with restricted diffusion in the olives, dorsal brainstem tracts, substantia nigra, periaqueductal gray matter and subthalamic nuclei (Figure 1). The MRI pattern was suggestive for cytochrome-c oxidase deficiency with SURF-1 mutation.

She was substituted with coenzyme $\mathrm{Q}_{10}(100 \mathrm{mg} /$ day $)$, carnitine (1 g/day) and high-dose multivitamin treatment (100 $\mathrm{mg}$ /day riboflavin, $100 \mathrm{mg} /$ day thiamine, $10 \mathrm{mg} /$ day biotin). One month after the initial presentation, recovery of ptosis was recognized. Molecular analyses revealed a homozygous c.518_538 (p.V173GfsX) deletion in SURF-1. After 7 months of follow-up, she presented with ataxic gait, confusion, nystagmus, and ptosis. Repeated brain MRI showed additional bilateral and symmetric lesions in the medial cerebellar hemispheres and superior cerebellar peduncles with restricted diffusion (Figure 2). It was learned from the family that they could not access drugs for 2 weeks.

Bilateral subthalamic nuclei involvement as T2 and fluidattenuated inversion recovery (FLAIR) hyperintense signal abnormality is a very common neuroimaging finding in Leigh syndrome (LS) with underlying SURF-1 mutations. The additional findings include T1-hypointense and T2 and FLAIR hyperintense signal abnormalities in the inferior olivary nuclei, inferior cerebellar peduncles, central tegmental tracts, reticular formation in the dorsal pons and periaqueductal gray matter in the midbrain $(1,2)$. Our patient had progressive neurologic disease, signs and symptoms of brainstem and/or basal ganglia disease, raised lactate levels in blood and/or CSF and characteristic features of LS on neuroimaging (hyperintense lesions on T2-weighted MRI) $(3,4)$.

Though LS is widely known to have a tendency to follow the course of progressive deterioration, we are acknowledge that several pathway-specific compounds such as thiamine and coenzyme $\mathrm{Q}_{10}$ have already been shown to be beneficial in patients. Our patient has already shown remarkable clinical improvement after management with high-dose vitamin and coenzyme $\mathrm{Q}_{10}$ treatment at the first attack, but it was known that spontaneous recovery could be misinterpreted as a positive therapeutic response as a result of the fluctuations of disease severity (5). A high index

Address for Correspondence/Yazışma Adresi: Özge Dedeoğlu MD, Dr. Sami Ulus Children's Hospital, Clinic of Pediatric Neurology, Ankara, Turkey Phone: +903123056000 E-mail: ozgem.dr@gmail.com ORCID ID: orcid.org/0000-0002-7492-5255

Received/Geliş Tarihi: 11.08.2017 Accepted/Kabul Tarihi: 05.12.2017

${ }^{\circ}$ Copyright 2018 by Turkish Neurological Society

Turkish Journal of Neurology published by Galenos Publishing House. 

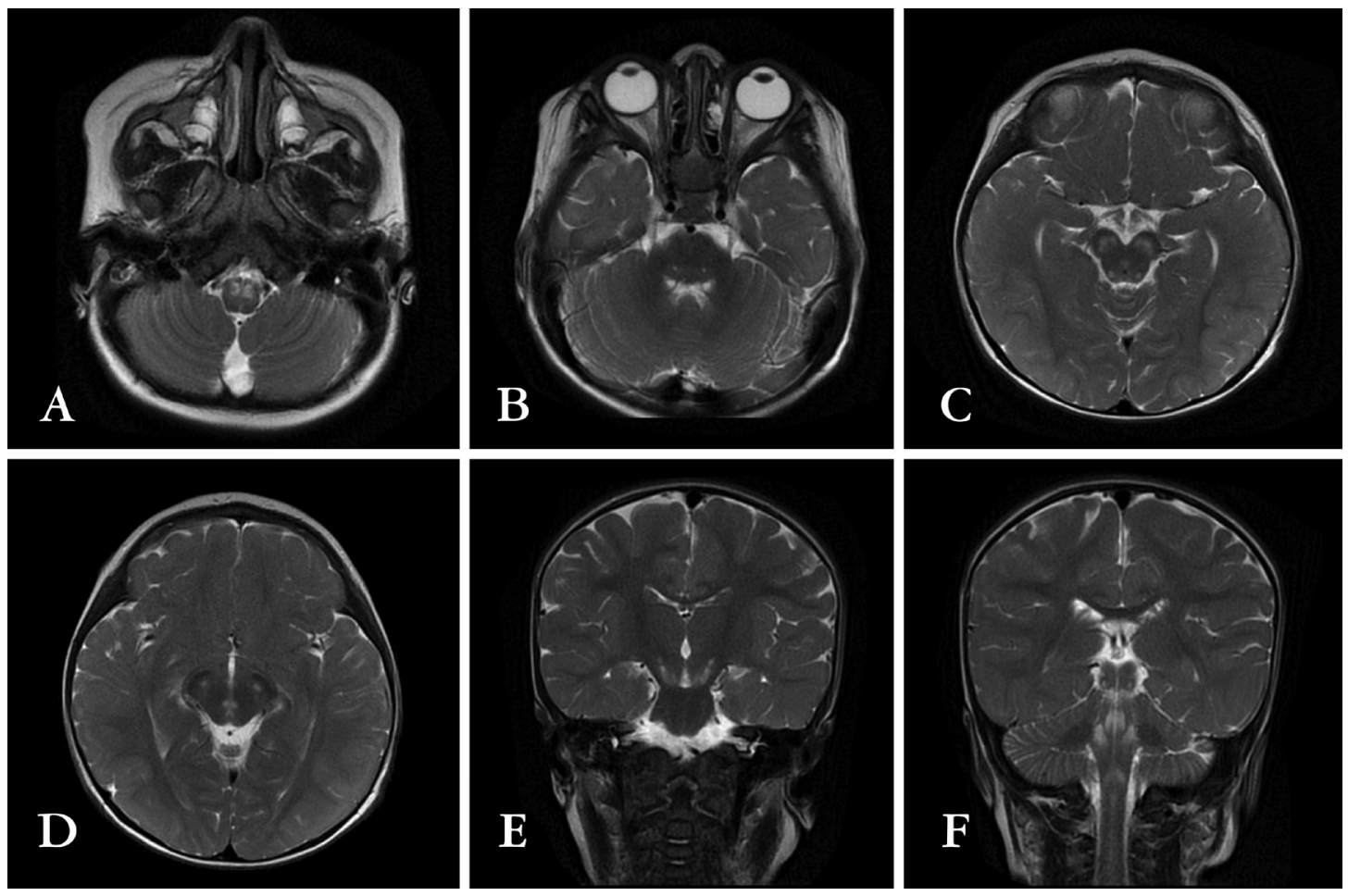

Figure 1. Axial (A, B, C, D) and coronal (E, F) T2-weighted images (TR/TE: 3000/100 ms) show bilateral and symmetric lesions of the inferior olivary nuclei, dorsal brainstem tracts, substantia nigra, periaqueductal gray matter, and subthalamic nuclei.
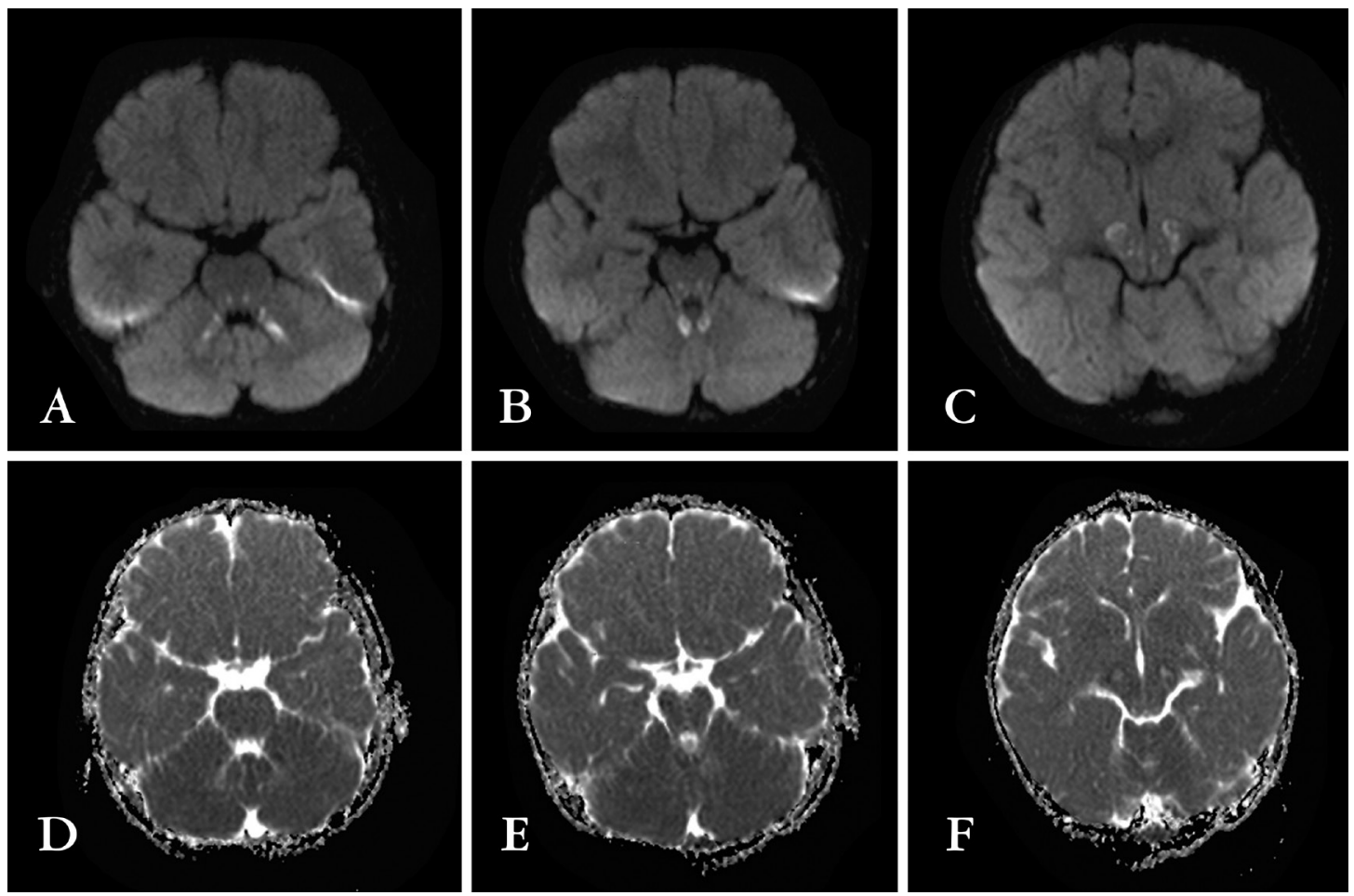

Figure 2. Axial isotropic trace diffusion-weighted images (TR/TE: 6600/89 ms with a maximum b value of $\left.1000 \mathrm{~s} / \mathrm{mm}^{2}\right)(\mathrm{A}, \mathrm{B}, \mathrm{C})$ obtained at 7 months repeat imaging show additional new bilateral lesions in the medial cerebellar parenchyma and superior cerebellar peduncles and substantia nigra in the cerebral peduncle. Corresponding apparent diffusion coefficient maps (D, E, F) reveal low values in the lesions. 
of suspicion combined with a knowledge of ocular manifestations and the correlation of typical imaging features can help make the correct diagnosis.

\section{Ethics}

Informed Consent: Informed consent was obtained from patient's parent.

Peer-review: Internally peer-reviewed.

\section{Authorship Contributions}

Concept: Ö.D., Design: Ö.D., Ç.G.S., Data Collection or Processing: Ö.D., Analysis or Interpretation: Ö.D., D.Y., M.K., K.K.O., B.T., Literature Search: Ö.D., Writing: Ö.D., M.K.

Conflict of Interest and Financial Disclosure: The authors whose names are listed above certify that they have no affiliations with or involvement in any organization or entity with any financial interest in the subject master or materials discussed in this manuscript. The genetic analyses was tested by Damagen laboratory.

\section{References}

1. Rossi A, Biancheri R, Bruno C, Di Rocco M, Calvi A, Pessagno A, TortoriDonati P. Leigh Syndrome with COX deficiency and SURF1 gene mutations: MR imaging findings. AJNR Am J Neuroradiol 2003;24:1188-1191.

2. Bosemani T, Anghelescu C, Boltshauser E, Hoon AH Jr, Pearl PL, Craiu D, Johnston MV, Huisman TA, Poretti A. Subthalamic nucleus involvement in children: a neuroimaging pattern-recognition approach. Eur J Paediatr Neurol 2014;18:249-256.

3. Ogawa E, Shimura M, Fushimi T, Tajika M, Ichimoto K, Matsunaga A, Tsuruoka T, Ishige M, Fuchigami T, Yamazaki T, Mori M, Kohda M, Kishita Y, Okazaki Y, Takahashi S, Ohtake A, Murayama K. Clinical validity of biochemical and molecular analysis in diagnosing Leigh syndrome: a study of 106 Japanese patients. J Inherit Metab Dis 2017;40:685-693.

4. Rahman S, Blok RB, Dahl HH, Danks DM, Kirby DM, Chow CW, Christodoulou J, Thorburn DR. Leigh syndrome: clinical features and biochemical and DNA abnormalities. Ann Neurol 1996;39:343-351.

5. Pfeffer G, Horvath R, Klopstock T, Mootha VK, Suomalainen A, Koene S, Hirano M, Zeviani M, Bindoff LA, Yu-Wai-Man P, Hanna M, Carelli V, McFarland R, Majamaa K, Turnbull DM, Smeitink J, Chinnery PF. New treatments for mitochondrial disease-no time to drop our standards. Nat Rev Neurol 2013;9:474-481. 